\title{
THE EFFECT OF DUAL TASK TRAINING ON STATIC AND DYNAMIC BALANCE OF OLDER ADULTS HAVING INSTITUTIONAL LIVING: RANDOMIZED TRIAL
}

\section{Abstract}

Turkish Journal of Geriatrics DOI: 10.31086/tjgeri.2018.69 2018;21 (4):617-626

- Begüm SARIPINARLI ${ }^{1}$

- Habibe Serap INAL ${ }^{2}$

CORRESPONDANCE

Begüm SARIPINARLI

Okan University, Physiotherapy and

Rehabilitation, İstanbul, Turkey

Phone: 02166771630

e-mail: b.saripinarli@gmail.com

Received: 07/02/2018

Accepted: 02/11/2018

Okan University, Physiotherapy and

Rehabilitation, Istanbul, Turkey

Bahçeşehir University, Physiotherapy and

Rehabilitation, İstanbul, Turkey

Introduction: In the presented study it was aimed to observe the effects of dual-task on static and dynamic balance and to present if static and dynamic balance training under dualtask performance effect the static and dynamic balance ability positively among the older adults having an institutional living.

Materials and Method: Fifty volunteer individuals $(72.02 \pm 6.60$ years of age, ranging between 64 and $91 ; 12 \%$ women, $n=6,88 \%$ men, $n=44$ ) took part in this study. Evaluations as Barthel Activity of Daily Living Index, Berg Balance Scale and Berg Balance Scale Under Dual-Task Performance were performed both before and after trainings. The participants were divided into two groups by computer-generated randomization table: Group A ( $n=26$, number of sessions $=5$ ) and Group B ( $n=24$, number of sessions=7).

Results: Balance score was not affected by dual-task performance, and no differences were found between groups ( $p>0.05$ ). For groups, balance score both with and without dual-task performance showed positive improvement after training $(p=0.00)$.

Conclusion: Training had positive effects for both group's balance with and without dualtask performance, but not affected by the session numbers. Physiotherapists should prefer 5 training instead of 6,7 or 8 . Yet it could be cost-effective by providing important health benefits, time gains, labor force at relatively low cost. Besides, the study offers standardized flow for both assessment and training on balance under dual-task performance for the older adult population

Keywords: Task Performance and Analysis; Activities, Daily Living; Aged

ARASSTIRMA

\section{ÇIFT GÖREV EĞiTIMININ KURUMDA YAŞAYAN YAŞLI BIREYLERDE STATIK VE DINAMIK DENGEYE ETKILERI: RANDOMIZE ARAŞTIRMA}

\section{$\ddot{O ̈ z}$}

Giriş: Bu çalışmada çift görevin statik ve dinamik denge üzerindeki etkilerini gözlemleyerek etkilerini ortaya koymak amaçlanmıştır.

Gereç ve Yöntem: Amaç doğrultusunda; 50 gönülü bireyin $(72.02 \pm 6.60,64-91 ; 12 \%$ kadın $n=6,88 \%$ erkek $n=44$ ) fonksiyonel durumu (Barthel Günlük Yaşam Aktivite İndeksi), statik ve dinamik dengesi (Berg Balans Skalası) ve çift görev altında statik ve dinamik dengesi (Çift Görev altında Berg Balance Skalası) değerlendirildi. Tüm gönüllüler Türkiye Cumhuriyeti Darülaceze Müdürlüğü'nde yaşayan ve 65 yaş üstü bireylerdi. Bilgisayar tabanlı randomizasyon tekniği ile iki grup oluşturuldu: Grup A ( $n=26,5$ seans) ve Grup B ( $n=24,5$ seans üstü). Çift görev performansı altında verilen statik ve dinamik denge eğitimlerinden sonra iki grubun dengeleri Berg Balans Skalası ve Çift Görev altında Berg Balance Skalası ile değerlendirildi. Elde edilen veriler grup içi ve gruplar arası istatistiksel analizlerle karşılaştıııldı.

Bulgular: Katılımcıların sosyo-demografik özellikleri ile fonksiyonel bağımsızlıkları arasında anlamlı bir fark bulunmadı ( $p>0.00$ ). Sonuçlara göre, denge puanı çift görev performansından etkilenmemiştir ve gruplar arasında fark bulunmamıştır $(p>0.05)$. Hem denge hem de çift görev performansı altında denge skorlarında, eğitimler sonrasında anlamlı gelişmeler görüldü $(p=0.00)$.

Sonuç: Eğitimler, iki grupta da denge ve çift görev altında denge performanslarını olumlu etkiledi, ancak eğitimlerin seans sayısı bir fark yaratmadı. Bu nedenle eğitim planlamasında; 6,7 veya 8 seans yerine 5 seans tercih edebilir. Böylelikle; beklenen yarar sağlanarak, vakitten iş gücünden kazanç sağlayarak ve nispeten daha az sağlık harcaması yaparak maliyet - yarar ilişkisinde kar elde edilebilir. Bunun yanı sıra çalışmamızda çift görev performansı altında denge değerlendirmesi ve eğitimi adına standardize edilmiş bir akıs önerilmektedir.

Anahtar sözcükler: Görev Performansı; Denge; Eğitim; Yaşlı 


\section{INTRODUCTION}

The elderly population is substantially increasing in the 21st century. Between 2000 and 2015, it increased from $11 \%$ to $22 \%$. The Turkish elderly population also proportionally increases. According to the population projections reported by the Turkish General Directorate of Population and Citizenship Affairs, the total percentage of individuals higher then 65-year-old in Turkey is currently $8.3 \%$; it is projected to reach $10.2 \%$ in 2023, $20.8 \%$ in 2050 , and $27.7 \%$ in 2075 (1). Therefore, the globally increasing percent of older adult population, the literature is mostly focusing on their physical and cognitive performances that are having liability to decrease due to aging (1-3).

Falls and loss of balance are the most common physical problems faced by older adults usually occur while standing and performing one task or a complex task at the same time (4), which is called dualtasking. Dual-tasking involves complex, strenuous, and advanced neurophysiological processes of the brain and body that require highly cognitive function (5). As the level of activity increases, the higher level of attention for performing the tasks, which may be physical, cognitive or combined tasks are required. Such as monitoring a phone call while walking or attempting to remember someone's name while running, carrying a filled cup of water while walking $(6,7)$, may reduce attentional processing capacity and limit postural control abilities of older adults (4). This may result with limitations in their balance and postural control (8). However, these may also be affected negatively with the verbal tasks (5); such as counting backward from hundred, sorting the vegetables according to their colors while performing physical tasks.

Thus, the recent approaches in walking and balance trainings have included dual-and multitasking activities to improve both balance and cognitive performances of older adults (6-9).

The systematic review of Gobbo et al. (10) reached to the outcome that there is a lack of evidence reporting the exercise protocol and number of sessions on balance in healthy older adults during dual-task performance. Additionally, various numbers of training sessions as 5 to 25 were found for dual-task training in the literature (5-11). Yet, there are controversial results of the studies searching effectiveness of dual-task training on static and dynamic balance of older adults. Therefore, the aim of this study is to observe the effectiveness of dual-task training on static and dynamic balance performance of older adults as well as the number of sessions efficient to improve the balance under dual-task performance. In the light of this knowledge, we hypothesized that the balance and walking training under dual-task performance improves the static and dynamic balance of older adults having institutionalized living.

\section{MATERIALS AND METHOD}

The study presented is a randomized controlled clinical study conducted with older adults living in the institutional setting of Darulaceze Presidency, which was first established in 1863 for those having no financial or family support. The study was designed to observe the effects of dual task training on static and dynamic balance of older adults as well as to state the minimum number of sessions required to reach positive effects on balance and dual tasks among the participants. The study was approved by the Ethics Committee of Bahçeşehir University (Turkey) (4/1/2017 date, 2017-01/05 numbered decision) and the written consent was received from participants prior to the evaluation in accordance with the principles of the Helsinki Declaration.

\section{Participants}

The fifty $(n=50)$ participants out of 152 were included according to the criteria of the study as shown in the flow chart (Figure 1). The participants assigned into two groups by using the computer generated randomization table of numbers created prior to the beginning of the study as 
Group A $(n=26)$ having 5 sessions of trainings and Group B ( $n=24)$ having more than 5 sessions of trainings (9 participants had 6 sessions; 6 participants had 7 sessions; 9 participants had
8 sessions; mean session number:7.00) (Table 1). A brief explanation to participants about assessments and trainings were conducted by the same physical therapist.

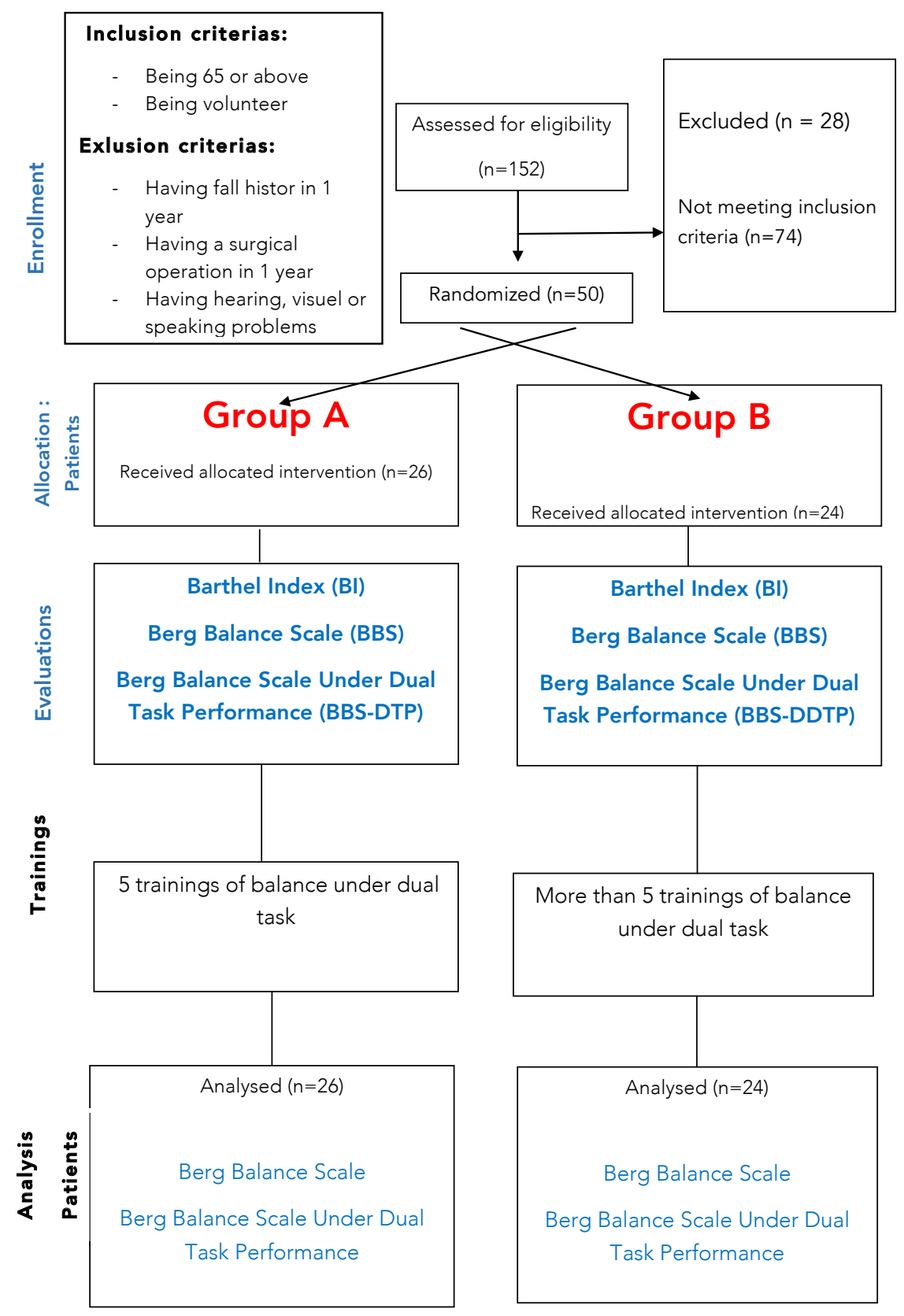

Figure 1. Flow Chart of the study. 
Table 1. The socio-demographic features of the participants.

\begin{tabular}{|c|c|c|c|c|c|c|}
\hline \multirow{7}{*}{ Group A } & $\begin{array}{l}\text { Participants } \\
(n=50)\end{array}$ & & Frequency & Ratio (\%) & $X \pm s d$ & $\mathrm{p}$ \\
\hline & \multirow{2}{*}{ Gender } & $\mathrm{F}$ & 4 & 15,4 & $24.17 \pm 14.52$ & \multirow[t]{2}{*}{$0,01^{\circ}$} \\
\hline & & $M$ & 22 & 84,6 & $37.82 \pm 11.22$ & \\
\hline & Age (years) & $\begin{array}{l}64-91 \\
(71.31 \pm 5.58)\end{array}$ & 26 & & & \\
\hline & \multirow{3}{*}{ Education } & No education & 6 & 23,1 & $36.33 \pm 12.22$ & \multirow{3}{*}{$0.70^{\mathrm{k}}$} \\
\hline & & Primary school & 18 & 69,2 & $37.60 \pm 12.12$ & \\
\hline & & $\begin{array}{l}\text { High school } \\
\text { University }\end{array}$ & $\begin{array}{l}2 \\
0 \\
\end{array}$ & $\begin{array}{r}7,7 \\
0 \\
\end{array}$ & $\begin{array}{r}32.83 \pm 13.75 \\
- \\
\end{array}$ & \\
\hline \multirow{7}{*}{$\begin{array}{l}\text { Group } \\
\text { B }\end{array}$} & \multirow{2}{*}{ Gender } & $\mathrm{F}$ & 2 & 8,3 & $25.83 \pm 15.29$ & \multirow[t]{2}{*}{$0.01^{\circ}$} \\
\hline & & $M$ & 22 & 91,7 & $39.61 \pm 11.04$ & \\
\hline & Age & $\begin{array}{l}64-91 \\
(72.79 \pm 7.61)\end{array}$ & 24 & & & \\
\hline & \multirow{4}{*}{ Education } & No education & 12 & 50,0 & $38.94 \pm 12.21$ & \multirow{4}{*}{$0.65^{b}$} \\
\hline & & Primary school & 7 & 29,2 & $38.64 \pm 12.01$ & \\
\hline & & High school & 4 & 16,7 & $35.67 \pm 13.54$ & \\
\hline & & University & 1 & 4,2 & $33.17 \pm 10.88$ & \\
\hline
\end{tabular}

a: Mann Witney U Test;

b: Kruskal Wallis H Test

All participants were evaluated at the beginning of the study for functional independence (Barthel Activity of Daily Living Index-Barthel ADL Index) $(12,13)$. Than both of the groups were evaluated at the beginning and end of the trainings (Group $A$ at the end of $5^{\text {th }}$ training; Group $B$ at the end of the trainings following weeks after the $5^{\text {th }}$ week, as $6^{\text {th }}, 7^{\text {th }}$, and $8^{\text {th }}$ as they required) for balance (Berg Balance Scale-BBS) $(14,15)$ and balance under dual-task (Berg Balance Scale under Dual Task Performance-BBS-DTP).

\section{Instruments}

Bathel Activity of Daily Living Index (Barthel $A D L$ Index)

Barthel Activity of Daily Living Index is a 10- item daily life inventory scored between 0 and 100; 0-20 indicates fully dependence, 21-61 high level dependent, 62-90 moderately dependent, 91-99 low level dependent and 100 indicates independence in daily living activities. Intraclass Correlation Coefficiency (ICC) of Barthel Index was reported as $0.88(12,13)$.

\section{Berg Balance Scale (BBS)}

The Berg Balance Scale is an objective balance scale that measures static and dynamic balance capabilities that has 14 functional tasks and daily living activities. It is scored from 0-56 points on sitting, standing, changing positions while sitting and standing, standing with eyes closed, reaching forward in standing, taking an object from floor standing on one leg or on both 
while they are together, turning, stepping forward. The first five activities in the test were formed to measure simple balance movements and the last nine activities to measure high level of balance movements. Each activity was scored from 0-4, and a score less then 45 points indicates the elderly may be at greater risk of falling (14).

The Turkish reliability and validity study of the Berg Balance Scale has been conducted by Sahin et al and proven effective in determining balance and postural control of individuals over 65 years of age. Intraclass Correlation Coefficiency of the Turkish version of the BBS was determined as 0.98 for the total score (15).

Berg Balance Scale under Dual Task Performance (BBS-DTP)

Fourteen dual-tasks consisting of verbal fluency, visual search and calculation tasks were defined for each sub-parameter of Berg Balance Scale for the participants to perform their balance under dual-tasks (Tablo 4) (10). The participants were expected to perform the sub-parameters of Berg Balance Scale, while doing the defined physical tasks at the same time, and their performances were recorded as BBS-DTP score. Berg Balance Scale provides motor task and additional dual-tasks selected as verbal, visual or calculation task from the cognitive tasks.

\section{Trainings}

The standardized static and dynamic balance training under dual-task performance $(10,14,15)$ in the concept of Berg Balance Scale items were given once a week for 45 minutes as a face-toface session for each group (Figure 2) (Tablo 4). The training program was specifically designed by combining the sub-parameters of Berg Balance Scale with the tasks requiring verbal (10 items), visual (2 items) and calculation (2 items) assignments.

\section{Statistical analysis}

For statistical analysis, SPSS Statistics 22.0 was used. Distribution was determined by the Shapiro-Wilk and Kolmogorov-Smirnov tests. For normally distributed and non-normally distributed data, parametric tests and non-parametric tests were used, respectively. Variables were defined with mean and standard deviation values. The data within group were assessed with Paired Sample $t$ Test and between the groups with the Independent Sample t- and a Kruskal-Wallis $\mathrm{H}$ Tests. The difference between the groups we analyzed by a $95 \%$ confidence level and $p<0.05$ value were considered as statistically significant.

\section{RESULTS}

According to the outcomes of the study, there were no significant difference among the sociodemographic features of the participants in both group (Table $1 ; p>0,05)$. There were also no difference in the level of the daily living activities of both of the groups. Group A, who had 5 sessions of trainings (78.84 \pm 14.16$)$ and Group $B$ who had more than 5 sessions of trainings (78.54 \pm 17.59$)$, were moderately dependent according to the Barthel Acitivites of Daily Living Index (Table 2).

According to the Berg Balance Scale with and without under dual task, both of the groups benefited from the training program given in the sessions $(p<0.05)$. However, we have not found any difference between the outcomes of the groups (Table 3). Thus, we found that 5 sessions of balance or balance under dual task training designed in the concept of Berg Balance Scale was effective to improve the balance of the participants. This points out that five sessions of balance training program under dual task can be suggestible. 
Table 2. The comparison of the outcomes of the both groups in relation to functional independence assed by Bathel Activity of Daily Living Index (Group A n=26; Group B n=24).

\begin{tabular}{|c|c|c|c|c|c|}
\hline $\begin{array}{l}\text { Parameter } \\
\text { (min - max values) }\end{array}$ & Group & $\bar{x}$ & sd & $t$ & $p^{a}$ \\
\hline \multirow{2}{*}{$\begin{array}{l}\text { Feeding } \\
(0-10)\end{array}$} & A & 9.615 & 1.359 & \multirow{2}{*}{-.515} & \multirow{2}{*}{.609} \\
\hline & $B$ & 9.792 & 1.021 & & \\
\hline \multirow{2}{*}{$\begin{array}{l}\text { Transfer } \\
(0-5)\end{array}$} & & 12.308 & 3.234 & \multirow{2}{*}{1.480} & \multirow{2}{*}{.146} \\
\hline & B & 10.833 & 3.807 & & \\
\hline \multirow{2}{*}{$\begin{array}{l}\text { Grooming } \\
(0-5)\end{array}$} & $A$ & 3.269 & 2.426 & \multirow{2}{*}{-.730} & \multirow{2}{*}{.469} \\
\hline & $B$ & 3.750 & 2.212 & & \\
\hline \multirow{2}{*}{$\begin{array}{l}\text { Toilet use } \\
(0-10)\end{array}$} & $A$ & 8.077 & 2.481 & \multirow{2}{*}{.857} & \multirow{2}{*}{.396} \\
\hline & B & 7.292 & 3.895 & & \\
\hline \multirow{2}{*}{$\begin{array}{l}\text { Bathing } \\
(0-5)\end{array}$} & $A$ & 2.308 & 2.542 & \multirow{2}{*}{-1.151} & \multirow{2}{*}{.256} \\
\hline & B & 3.125 & 2.473 & & \\
\hline \multirow{2}{*}{$\begin{array}{l}\text { Mobility } \\
(0-15)\end{array}$} & $A$ & 12.692 & 3.530 & \multirow{2}{*}{-.223} & \multirow{2}{*}{.825} \\
\hline & $B$ & 12.917 & 3.586 & & \\
\hline \multirow{2}{*}{$\begin{array}{l}\text { Stairs } \\
(0-10)\end{array}$} & A & 5.769 & 2.717 & \multirow{2}{*}{1.184} & \multirow{2}{*}{.242} \\
\hline & B & 4.792 & 3.120 & & \\
\hline \multirow{2}{*}{$\begin{array}{l}\text { Dressing } \\
(0-10)\end{array}$} & $A$ & 7.115 & 2.519 & \multirow{2}{*}{-1.745} & \multirow{2}{*}{.087} \\
\hline & $B$ & 8.333 & 2.408 & & \\
\hline \multirow{2}{*}{$\begin{array}{l}\text { Bowel } \\
(0-10)\end{array}$} & A & 9.423 & 1.629 & \multirow{2}{*}{.102} & \multirow{2}{*}{.919} \\
\hline & $B$ & 9.375 & 1.689 & & \\
\hline \multirow{2}{*}{$\begin{array}{l}\text { Bladder } \\
(0-10)\end{array}$} & $A$ & 7.885 & 3.217 & \multirow{2}{*}{-.278} & \multirow{2}{*}{.783} \\
\hline & $B$ & 8.125 & 2.879 & & \\
\hline \multirow{2}{*}{$\begin{array}{l}\text { Total score } \\
(0-100)\end{array}$} & A & 78.846 & 14.164 & \multirow{2}{*}{.068} & \multirow{2}{*}{.946} \\
\hline & $B$ & 78.542 & 17.599 & & \\
\hline
\end{tabular}

a: Independent T Test 
Table 3. Comparison of the outcomes of both groups balance scores with and without Dual Task Performance (BBS and BBS-DTP) both before and after trainings.

\begin{tabular}{|c|c|c|c|c|c|c|c|c|c|}
\hline \multicolumn{4}{|c|}{$\begin{array}{c}\text { Before } \\
\text { training }\end{array}$} & \multicolumn{4}{|c|}{$\begin{array}{c}\text { After } \\
\text { training }\end{array}$} & \multicolumn{2}{|c|}{$\begin{array}{c}\text { Difference } \\
\text { between groups }\end{array}$} \\
\hline Group & $\bar{X} \pm s d$ & $\mathbf{t}$ & $\mathrm{Pa}$ & Group & $\bar{X} \pm s d$ & $\mathrm{t}$ & $p^{a}$ & $\mathbf{t}$ & $p^{b}$ \\
\hline $\begin{array}{l}\text { A } \\
\text { (BBS) }\end{array}$ & 35.8112 .47 & -0.220 & 0.83 & $\begin{array}{l}\text { A } \\
\text { (BBS) }\end{array}$ & 37.1512 .40 & -0.478 & 0.63 & -3.505 & 0.00 \\
\hline $\begin{array}{l}\text { B } \\
\text { (BBS) }\end{array}$ & 36.5812 .44 & & & $\begin{array}{l}\text { B } \\
\text { (BBS) }\end{array}$ & 38.8312 .40 & & & -6.608 & 0.00 \\
\hline $\begin{array}{l}\text { A } \\
\text { (BBS-DTP) }\end{array}$ & 33.0411 .42 & -0.143 & 0.89 & $\begin{array}{l}\text { A } \\
\text { (BBS-DTP) }\end{array}$ & 34.9212 .09 & -0.270 & 0.79 & -3.767 & 0.00 \\
\hline $\begin{array}{l}\text { B } \\
\text { (BBS-DTP) }\end{array}$ & 33.5011 .43 & & & $\begin{array}{l}\text { B } \\
\text { (BBS-DTP) }\end{array}$ & 35.8311 .74 & & & -6.402 & 0.00 \\
\hline
\end{tabular}

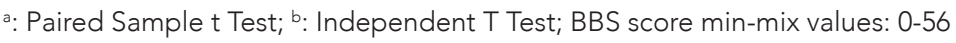
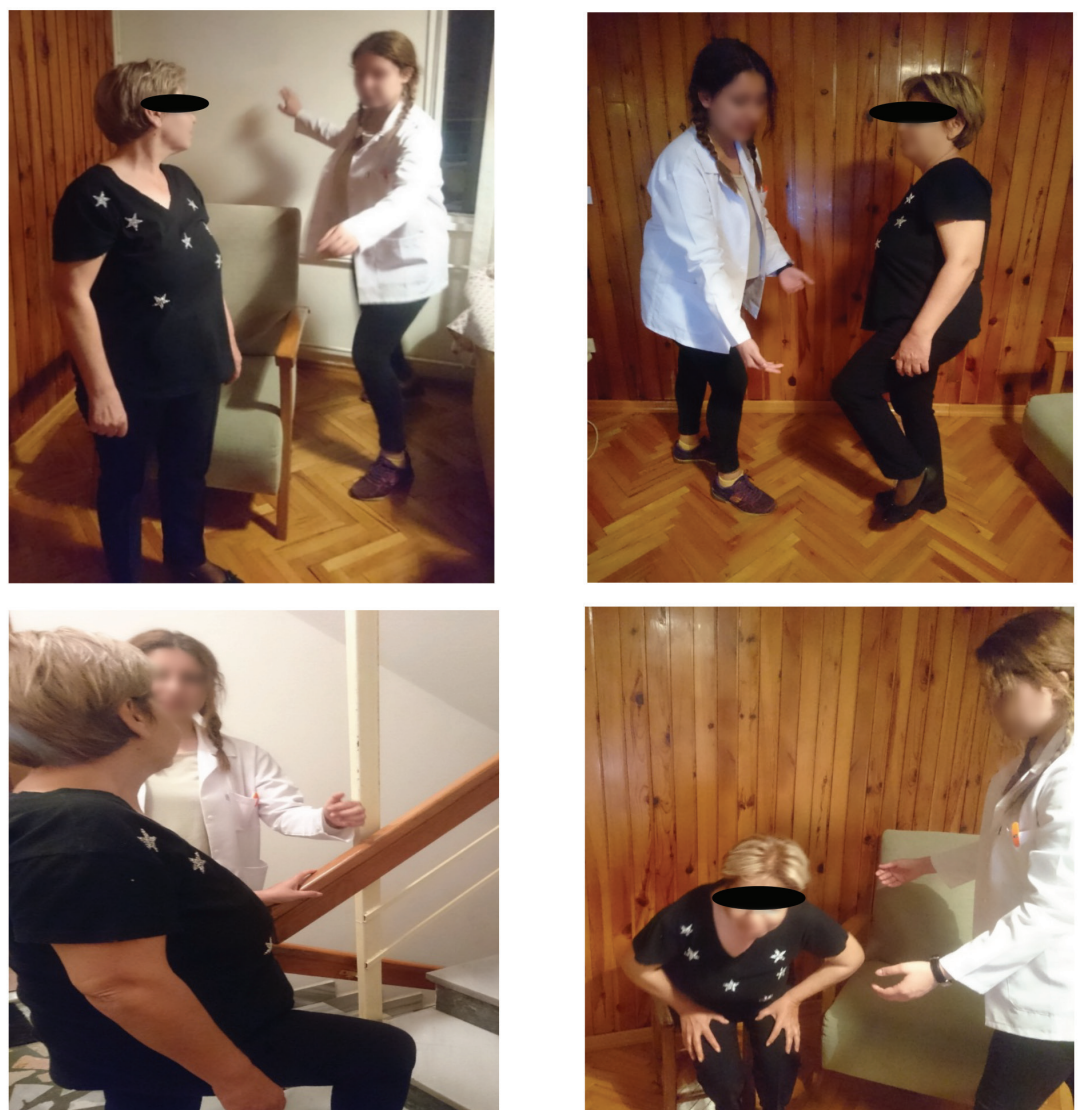

Figure 2. Balance trainings under dual task performance of one of the participants. 
Table 4. Specified Dual Tasks given during balance training and Berg Balance Test interventions (BBS-DTP).

\begin{tabular}{|c|c|c|c|}
\hline No & $\begin{array}{l}\text { Type } \\
\text { of task }\end{array}$ & BBS Sub-parameters & Specified Dual Tasks \\
\hline 1 & VFT & Sitting to stand & Give some example to green vegetables \\
\hline 2 & VFT & Standing unsupported & Give some example to sports done with a ball \\
\hline 3 & VFT & Sitting unsported & Named the geographic areas of Turkey \\
\hline 4 & VST & Standing to sitting & Named the colours of rainbow \\
\hline 5 & VFT & Transfers & Name the days of week \\
\hline 6 & VFT & Standing with eyes closed & Give example to cities starting with the capital letter " $\mathrm{K}$ ". \\
\hline 7 & $\mathrm{CT}$ & Standing with feet together & Count backwards from 100 \\
\hline 8 & CT & Reaching forward with outstretched arm & Count 5 from 50 \\
\hline 9 & VFT & Retrieving object from floor & Give some examples to most watched TV channels \\
\hline 10 & VST & Turning to look behind & Name the showed colour and object behind you \\
\hline 11 & VFT & Turning 360 degrees & Give some examples to fruits grown on trees \\
\hline 12 & VFT & Placing alternate foot on stool & Give some example to furnitures from house. \\
\hline 13 & VFT & Standing with one foot in front & Name the months in order \\
\hline 14 & VFT & Standing on one foot & Give some examples to organs \\
\hline
\end{tabular}

BBS: Berg Balance Scale; BBS-DTP: Berg Balance Scale under Dual Task Performance; VFT: Verbal Fluency Task; VST: Visual Search Task; CT: Calculation Task

\section{DISCUSSION}

We aimed to observe the effectiveness of the dualtask training on balance for the elderly having institutionalized living. The training program was specifically designed by combining the subparameters of Berg Balance Scale with the tasks requiring verbal (10 items), visual (2 items) and calculation (2 items) assignments. We have found that minimum 5 sessions of balance or balance under dual task training designed in the concept of Berg Balance Scale was effective to improve the balance of the participants. Colcombe et al.
(16) stated physical activity had positive effects on cognition and also stated that cognitive performance improves executive functioning to coordinate and control the behaviors. Strobach et al. (17) and Li et al. (5) targeted to improve motor performance with a cognitive dual task training protocol but as Li et al. announced at the end of the study, they do not claim cognitive trainings can substitute physical improvements. Therefore, in this study we focused on two functions by giving hybrid instruction, to achieve simultaneous motor and cognitive training to improve both motor and cognitive performance. 
Mengi et al. (18) who studied on people above $(n=18)$ and below $(n=18) 65$ years of age both with and without a history of falls by giving a dual task as walking while holding a filled cup of water as a dual-task (two physical tasks), found no significant difference between the fallers and non-fallers. They claimed that walking or holding a filled cup does not require a cognitive process and can be simultaneously done by automatic responses. However, in contrary, in this study we considered dual-tasks as a physical and cognitive assignment, combined with activities including static and dynamic balance not as automatic response. For this purpose, since it is known that a fall history is one of the risk factors for re-falling (19), we included fall history in the last one-year into the exclusion criteria of the study.

Besides the design of the dual-task training program the number of sessions are also important. Kimura et al. (11) reported that a dual-task training intervention to improve motor task performance for eight 15-minute sessions (totaling 120 minutes) improved motor task performance. In this research, as it was aimed to put forth the minimum training number that improves balance of elderly, we may state that 5 sessions for 45 minutes each (totally 225 minutes) is the minimum intervention duration. However, the greater the duration the greater the positive effects. On the other hand, the interest and motivation of the elderly to the sessions (11) as well as the cost effectiveness of the treatment programs may also be the other issues directing the rehabilitation team.

On contrary to these outcomes, there are studies showing the influence of one-session interventions with balance or dual-task training. Hamacher et al. (20) aimed to display the acute effects of single motor training and combined motor-cognitive training by assigning the exercise and dance groups, and reported the marked improvements in dynamic stability after one session of motorcognitive training. This may be due to the increased awareness of the motor-cognitive function. Since they also studied with elderly, further studies are needed to come up with effective outcomes on dual-task performances.

The statistical power of the study is 53\% according to Raosoft power analysis program. Since we used the cognitive tasks as for training and testing that combined with a well-known balance test, this may be suggestible as a new intervention for institutionalised elderly.

In conclusion, we may state that trainings of static and dynamic balance under Dual Task Performance are effective in institutionalized older adults. Therefore, it can be suggested that physiotherapists should plan balance training programs combined with cognitive skills, as physical and verbal, visual or calculation dual tasks together for older population at least 5 sessions. Preferring 5 sessions of trainings instead of 6,7 or 8 could also be cost-effective by providing important health benefits, time saving, labor force at relatively low cost (21).

\section{ACKNOWLEDGEMENT}

We give our special thanks to; precious residents, president and physiotherapists in T.C Darulaceze Presidency for all their supports and insightfull comments.

\section{Conflict of interest}

We have no conflict of interest to declare. 


\section{REFERENCES}

1. Berg KO, Wood-Dauphinee S, Williams JI, Gayton D. Measuring balance in elderly: preliminary development of an instrument. Physiother Can 1989;41(6):304-311.

2. Colcombe S, Erickson K, ScalfP, et al. Aerobic exercise training increases brain volume in aging humans. The Journals Of Gerontology. Series A, Biological Sciences And Medical Sciences 2006;61(11):11661170. (PMID:17167157).

3. Gobbo S, Bergamin M, Sieverdes JC et al. Effects os exercise on dual-task ability and balance in older adults: a systematic review. Archieves of Gerontology and Geriatrics 2014;58(2):177-87. (PMID:24188735).

4. Gürkan A, Demirel H, Demir M, Atmaca E, Bozöyük G, Dane S. Effects of long-term training program on static and dynamic balance in young subjects. Clinical and Investigative Medicine 2016;39(6):31-3. (PMID:27917788)

5. Hamacher D, Hamacher D, Rehfeld K, \& Schega L. Motor-cognitive dual-task training improves local dynamic stability of normal walking in older individuals. Clinical Biomechanics 2016;32:138-141. (PMID:26682629).

6. Haripriya S, Anjana BS, George S, Babu Roshan PS. The influence of body mass index on functional mobility and balance in elderly individuals. Indian Journal of Physiotherapy \& Occupational Therapy 2017;11(1):6-10.

7. Kimura T, Kaneko F, Nagahata K, Shibata E, Aoki N. Working memory training Improves dual-task performance on motor tasks. Journal of Motor Behavior 2017;49(4):388-97. (PMID:27726513).

8. Konak H, Kibar S, Ergin E. The effect of singletask and dual-task balance exercise programs on balance performance in adults with osteoporosis: a randomized controlled preliminary trial. Osteoporosis International 2016;27(11):3271-8. (PMID:27234670).

9. Kucukdeveci AA, Yavuzer G, Tennant A, Suldur N, Sonel B, Arasil T. Adaptation of the modified Barthel Index for use in physical medicine and rehabilitation in Turkey. Scandinavian Journal of Rehabilitation Medicine 2000;32(2):87-92. (PMID:10853723).

10. Li KZH, Roudaia E, Lussier M, Bherer L, Leroux A, McKinley PA. Benefits of cognitive dual-task training on balance performance in healthy older adults. J Gerontol A Biol Sci Med Sci 2010;65(12):1344-52. (PMID:20837662).
11. Little CE, Woollacott M. Effect of attentional interference on balance recovery in older adults. Experimental Brain Research 2014;232(7):2049-60. (PMID:24639065).

12. Mahoney FI, Barthel DW. Functional evaluation: the barthel index, Maryland State. Med J 1965;(14):61-5. (PMID:14258950).

13. Manor B, Zhou J, Jorðdan A, et al. Reduction of dualtask costs by noninvasive modulation of prefrontal activity in healthy elders. Journal of Cognitive Neuroscience 2016;28(2):275-81. (PMID:26488591).

14. Mengi GT, Özyemişçi-Taşkıran ÖT, Taş NT. Balance, muscle strength and dual tasking in the elderly. Turkish Journal of Geriatrics 2010;13(3):178-84. (in Turkish).

15. Mengi GT, Özyemişçi-Taşkıran ÖT, Taş NT. Balance, muscle strength and dual tasking in the elderly. Turkish Journal of Geriatrics 2010;13(3):178. (in Turkish).

16. Munro J, Brazier J, Davey R, Nicholl J. Physical activity for the over-65s: could it be a cost-effective exercise for the NHS?. Journal of Public Health 1997;19(4):397402. (PMID:9467144).

17. Padala K, Padala $P$, Lensing $S$, et al. Efficacy of wiifit on static and dynamic balance in community dwelling older veterans: a randomized controlled pilot trial. Journal Of Aging Research 2017;1-9. (PMID:28261500).

18. Sahin F, Yilmaz F, Ozmaden A, Kotevoglu N, Sahin T, Kuran B. Reliability and validity of the Turkish version of the Berg Balance Scale. Journal of Geriatric Physical Therapy 2008;31(1):32-37. (PMID:18489806)

19. Strobach $T$, Salminen $T$, Karbach J, Schubert $T$. Practice-related optimization and transfer of executive functions: a general review and a specific realization of their mechanisms in dual tasks. Psychological Research 2014;78(6):836-51. (PMID:24668506).

20. Yang YR, Chen YC, Lee CS et al. Dual-task-related gait changes in individuals with stroke. Gait \& Posture 2007;25(2):185-90. (PMID:16650766).

21. Zoghi M, Kış M. The studies and results of elderly patients in Turkey. Archives of the Turkish Society of Cardiology 2017;45(5):143-6. (PMID:28976403). (in Turkish). 